Arch. histol. jap., Vol. 33, No. 4 (1971)

p. $351-355$

Department of Histology and Embryology (Prof. P. E. PetKov), Higher Medical Institute, Sofia, Bulgaria

\title{
Intranuclear Tubular Bodies in Islet Cells
}

\author{
S. Donev and P. Petkov
}

Received August 9, 1971

\begin{abstract}
Summary. Intranuclear tubular bodies are described in the pancreatic $A$ and $B$ cells of apparently healthy normal rabbits, rats, hedgehogs and pigs. The bodies consist of a central bundle of parallel tubules and a peripheral muff.

The intranuclear tubular bodies are considered to be normal structures in the cell nuclei.
\end{abstract}

There are already numerous descriptions in the literature of intracellular fibrillar and tubular structures. Several of them have an established structure and function, but this is not the case with the rare intranuclear filamentous and tubular formations. They have been described in the nuclei of different cells: by VIVIER and ANDRÉ, (1961) in the macronucleus of Paramecium caudatum; by Siegesmund et al. (1964) and by KARLSson et al. (1966) in the nuclei of nerve cells; by PhILLIPS (1965) in the nuclei of the cells of the salivary gland in Sciara diptera; by WeINDL et al. $(1967,1968)$ in the nuclei of the cells of the lamina terminalis in the dog; by LANE (1969) in actinomycin D-treated oocytes, and by DAHL (1970) in the nuclei of many cells of the normal hen, rat and monkey.

Intranuclear rod-shaped fibrillar structures have been found in most of the pancreatic islet B cells in obese-hyperglycemic mice by BoQUisT (1969). Up till now no filamentous or tubular formations have been described in the Langerhans islets of other animals although their ultrastructure has been studied in general (LACY and Louis, 1957; Munger, 1962; Lazarus et al., 1965; Munger et al., 1965).

\section{Material and Methods}

The pancreatic islets of the following normal animals of both sexes were studied: 8 rabbits, 5 Wistar rats, 4 pigs and 3 hedgehogs. The material was collected from March to June. The animals were kept on a standard laboratory diet drinking water ad lib. They were killed by decapitation. The pancreas was removed immediately after sacrifice and specimens were fixed by the following fixators: $1 \%$ osmium tetroxide in Milloning's buffer adjusted to $\mathrm{pH} 7.2-7.4$; and $4 \%$ glutaraldehyde in Millonig's buffer followed by $1 \%$ osmium tetroxide fixation (SABATINI et al. 1964).

After fixation the specimens were rinsed, dehydrated with ethanol, and embedded in Durcopan ASM. The sections were cut on an Ultramicrotome Reichert OMU-2 and stained with uranyl acetate after WATSON (1958) and lead citrate after REYNOLDS (1963). The observation was performed with the Hitachi U11A electron microscope.

\section{Results}

In some nuclei in the pancreatic islets of normal rabbit, white rat, hedgehog, and pig, there were detected fascicles of bar-shaped structures (Fig. 1). They have a 
length of $4 \mu$ and a diameter of about $0.1 \mu$. They are comparatively often observed in $A$ as well as in B cells of the investigated animals on the average in 2 or 3 cells per islet. In the rabbit however they are more frequently found in A cells than in B cells. Both logitudinal and transverse tubule profiles are seen but the transverse and oblique profiles predominate (Fig. 2). The tubular bodies in A and B cells in different animals do not generally differ in their structure from each other. They have the same appearance after osmium and glutaraldehyde fixation.

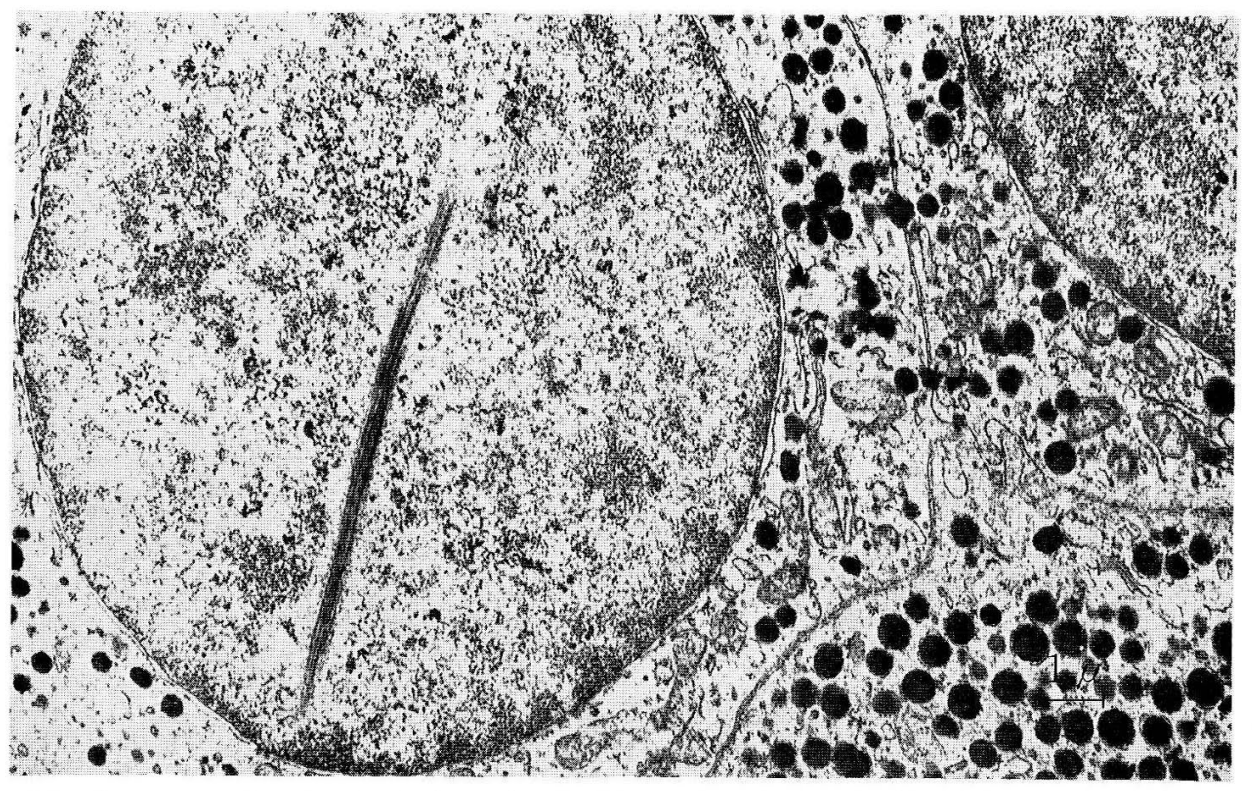

Fig. 1. Intranuclear tubular body in A cell of Langerhans' islet of rabbit. Osmium tetroxide.

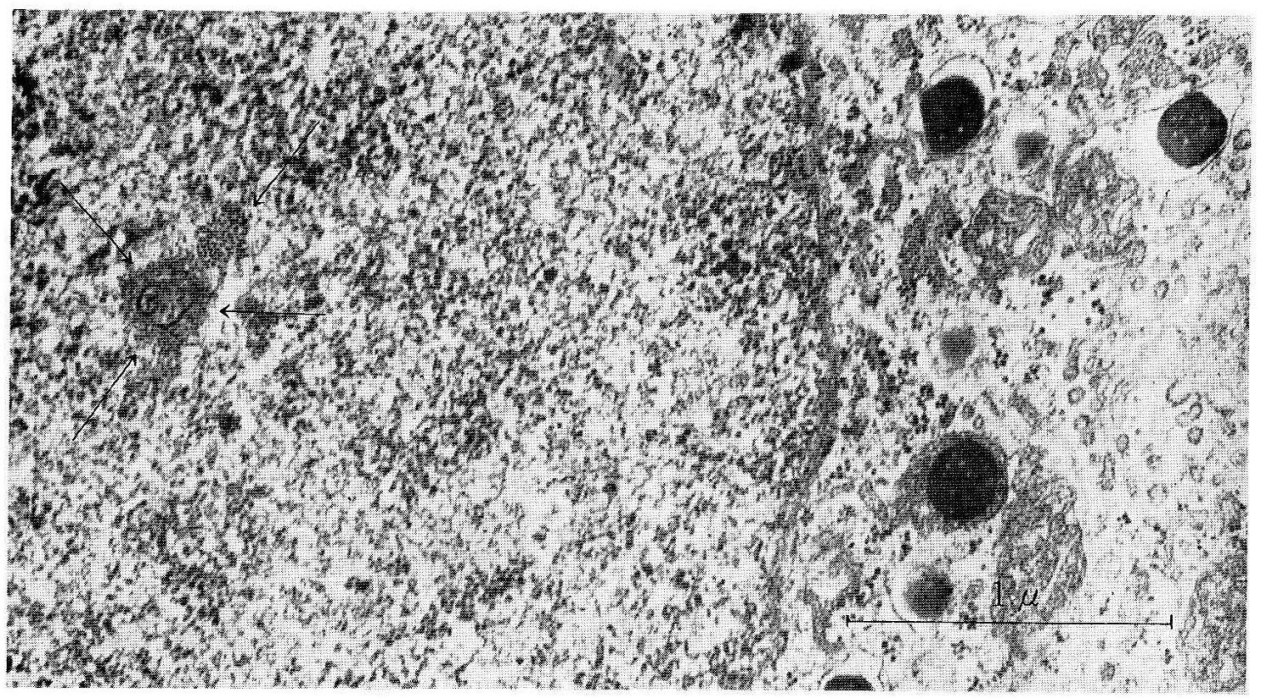

Fig. 2. Transversely cut intranuclear tubular body in B cell of rat. Osmium tetroxide. 


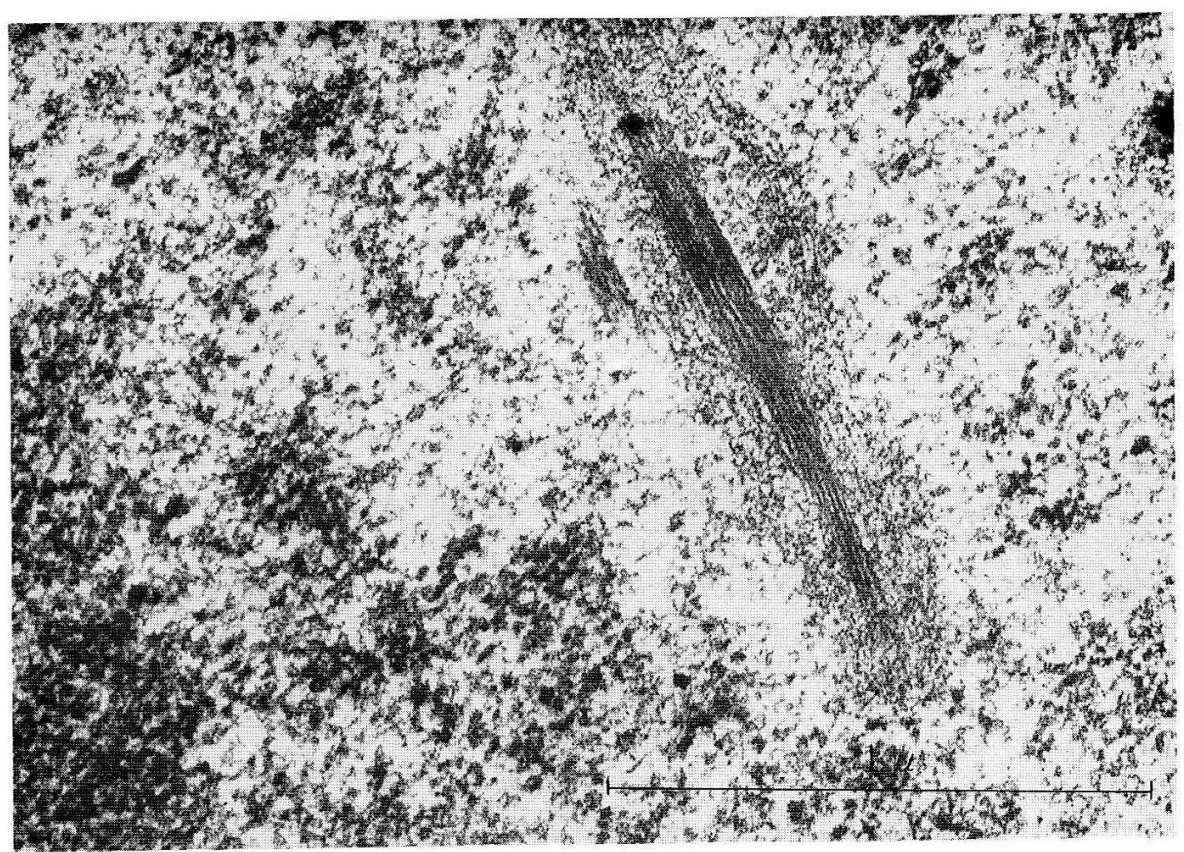

Fig. 3. Intranuclear tubular body in B cell of Langerhans' islet of rabbit. Central bundle of parallel tubules, surrounded by peripheral muff of cross-cut tubles. Osmium tetroxide.

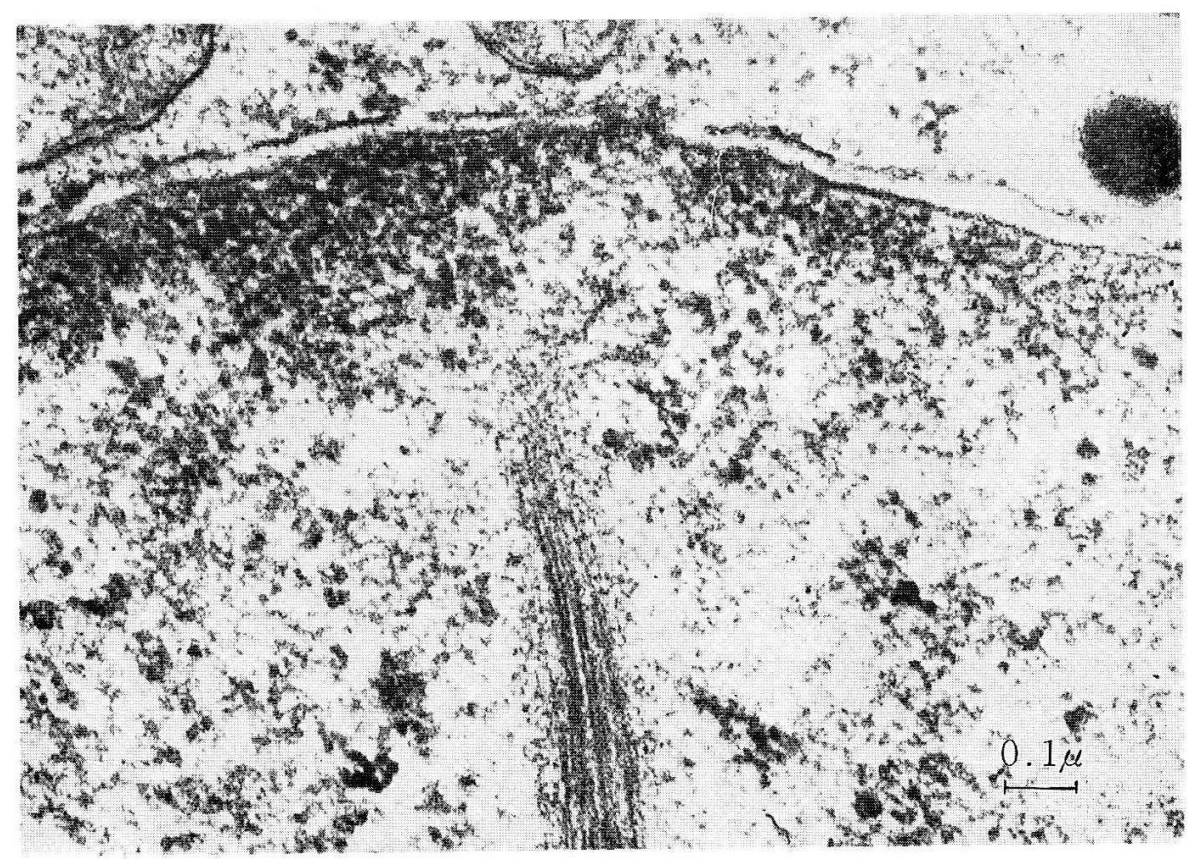

Fig. 4. Bundle of tubules in A cell nucleus of rabbit. Osmium tetroxide. 
In some of the B cells of the rabbit tubular bodies are observed whose central fascicle lies in a muff of a vesicular structure (Fig. 3). The central fascicle consists of 4-7 microtubules which are densely packed in parallel. The individual tubules are about $200 \AA$ in diameter with an interspace of $200-400 \AA$ (Fig. 4). Each tubule exhibits an electron-transparent core, $70-90 \AA$. The electron-opaque wall is $60-65 \AA$ thick. The peripheral muff has a total width of $0.3-0.4 \mu$. It is represented in Figure 2 around the central fascicle.

The membranes of the nuclei containing tubular bodies are unchanged. The outer membrane is covered by numerous ribosomes. The chromatin of these nuclei does not differ from that of the other islet's cells. The nucleoplasm surrounding the tubular formations shows a lower electron density than that in other parts of the nucleus (Fig. 3, 4).

There were no connections between the rods and the nucleoli or nuclear membrane.

As far as the appearance of cytoplasmic organelles is concerned-the Golgi complex, ergastoplasma, mitochondria and secretory granules, no difference was detected between the cells with the tubular bodies and the cells lacking in them.

\section{Discussion}

There are no available data in the literature on the presence of tubular structures in the nuclei of the endocrine pancreas in normal animals. With the present report we wish to point out that these tubular structures are to be found not only in the B cells of obese hyperglycemic mice and in its lean litter mates as reported by BoQUIST (1969), but also in normal and untreated rabbits, rats, pigs, and hedgehogs; they occur not only in the B but also in the A cells of the endocrine pancreas. The bodies described so far resemble in their morphology those observed by Weind et al. (1967) in the ependymal cells nuclei in the dog and by BoQUisT (1969) in the obese mouse B cells. The pictures we observed in transverse and longitudinal sections seem to indicate that they are characteristically organized tubular structures. These bodies are relatively frequently met in the A and B cells of the pancreatic islets of the rabbit, rat and hedgehog but they have not hitherto been described, because most of the investigators have directed their attention mainly to the cytoplasmic organelles. It must be pointed out, however, that our findings reveal only singular structures in small sizes.

According to LANE (1969) and BoQUisT (1969) the appearance of the filamentous bodies in the nucleus is connected to some pharmacological effect or some pathological state of the cell. However, the fact that these tubular formations are seen also in normal animals proves that they are formations which normally exist in the nucleus. This view is supported by the fact that the tubular bodies are found in cell nuclei with unchanged cell organelles implying that they are not pathological structure but normal ones. These bodies may well be found in pancreatic islet cells of other animals.

Their presence in the A as well as in the B cells of several animal species demonstrates that they are characteristic not only of the nuclei of one particular cell type and animal species. According to PHILliPs (1965) the bodies of this type are bound to DNA metabolism, but LANE (1969) considers them neither bound to DNA nor RNA as they react negatively in the histochemical methods for DNA and RNA and no 
radioactive uridine $\mathrm{H}^{3}$ is incorporated in them. Some authors (VIVIER and ANDRÉ, 1961; Lane, 1969; GArreau de Loubresse, 1970) presume that the filamentous and tubular structures in the nucleus have a protidic nature.

All the present findings suggest that the intranuclear tubular bodies are normal structures in the cell nuclei and that they do not respresent any pathological change.

\section{References}

Boquist, L.: Intranuclear rods in pancreatic islet B cells. J. Cell Biol. 43: 377-381 (1969).

Dahl, E.: The fine structure of nuclear inclusions. J. Anat. 106: 255-262 (1970).

Garreau de Loubresse, N.: Apparition de corps lamellaires au voisinage du nucléole dans les spermatides de Streptocephalus torvicornis W. (Crustacé phyllopode). C. r. Acad. Sci. (Paris) 270: 116-119 (1970).

Karlsson, U.: Three dimensional studies of neurons in the lateral geniculate nucleus of the rat. 1. Organelle organization in the perikaryon and its proximal branches. J. Ultrastr. Res. 16: 429-481 (1966).

Lacy, P. L. and St. Louis: Electron microscopy of the normal islets of Langerhans studies in the dog, rabbit, guinea pig and rat. Diabetes 6: 498-507 (1957).

Lane, N.: Intranuclear fibrillar bodies in actinomycin D-treated oocytes. J. Cell Biol. 40: 286-291 (1969).

Lazarus, S. and B. W. Volk: Ultrastructure and acid phosphate distribution in the pancreas of rabbit. Arch. Pathol. 80: 135-147 (1965).

Munger, B. L.: The secretory cycle of the pancreatic islet-cell. An electron microscopic study of normal and synthalin-treated rabbits. Lab. Invest. 11: 885-901 (1962).

Munger, B. L., F. Caramia and P. L. Lacy: The ultrastructural basis for the identification of cell types in the pancreatic islets. II. Rabbit, dog and opossum. Z. Zellforsch. 67: 776-798 (1965).

Phillips, D. M.: An ordered filamentous component in sciara (diptera) salivary gland cell nuclei. J. Cell Biol. 26: 677-683 (1965).

Reynolds, E. S.: The use of lead citrate at high $\mathrm{pH}$ as an electron-opaque stain in electron microscopy. J. Cell Biol. 17: 208-212 (1963).

Siegesmund, K. A., C. R. Dutta and C. A. Fox: The ultrastructure of the intranuclear rodlet in certain nerve cells. J. Anat. 98: 93-97 (1964).

Vivier, K. et J. André: Existence d'inclusions de ultrastructure fibrilaire dans le macro-nucleus de certains couches de Paramecium caudatum ehr. C. r. Acad. Sci. (Paris) 252: 1848-1850 (1961).

Watson, M.: Staining of tissue secretions for electron microscopy with heavy metals. J. biophys. biochem. Cytol. 4: 475-478 (1958).

Weindl, A., A. Schwink und R. Wetzstein: Intranucleare Tubuli-Bünel im Gefäßorgan der Lamina terminalis. Naturwiss. 54: 473 (1967).

Kaninchen. II. Das neuronale und gliale Gewebe. Z. Zellforsch. 85: 552-600 (1969).

Prof. Dr. P. E. Petkov

Institut d'Histologie

et d'Embryologie

Faculté de Médecine

Sofia 31, Bulgarie 